\title{
Credit Risk Management and the Performance of Financial Institutions in South Sudan
}

\author{
Adire Simon Deng*, Lucy Rono, Jane Sang \\ Department of Accounting \& Finance, Moi University, Kesses, Uasin Gishu County, Kenya \\ Email: ^geologistcamp@aol.com
}

How to cite this paper: Deng, A. S., Rono, C., \& Sang, J. (2020). Credit Risk Management and the Performance of Financial Institutions in South Sudan. Modern Economy, 11, 1919-1928. https://doi.org/10.4236/me.2020.1111128

Received: September 27, 2020

Accepted: November 23, 2020

Published: November 26, 2020

Copyright (c) 2020 by author(s) and Scientific Research Publishing Inc. This work is licensed under the Creative Commons Attribution International License (CC BY 4.0).

http://creativecommons.org/licenses/by/4.0/

\begin{abstract}
We study the relationship between Credit Risk Management and the performance of financial institutions in South Sudan using measures of institutional performance and Credit Risk Management. Using the ARDL model, we establish compliance with the basel accord significantly affecting the performance of finance institutions while monitoring corporate credit risk and risk management environment seem not to significantly exact influence the performance of financial institutions in South Sudan. On the other hand, credit risk operational practices seem to negatively and insignificantly affect the performance of financial institutions in the country.
\end{abstract}

\section{Keywords}

Credit Risk Management, Financial Institutions, Institutional Performance, South Sudan

\section{Introduction}

Performance is the driving force of every organization and organizations strive to achieve excellence in performance in all areas of operation. Adesugba \& Bambale (2016) argue that the objective of measuring performance does not only cover how a business is performing but also gives an insight on how business can perform better. Organizational performance is organization's capability to accomplish its goals effectively and efficiently using resources (Daft, 2000). Rezaei et al. (2018) regard organizational performance as the goals and achievement of a given organization. On the other hand, Ricardo \& Wade (2001) noted that achievement of organizational goals and objectives is considered organizational performance. Performance is a continuous and flexible process that involves managers and those whom manage acting as partners within a framework that sets out how they can best work together to achieve the required results 
(Armstrong, 2006). Firm performance is attained in a sequence of events that follow some logical flow starting from acquisition and configuration of resources, developing capabilities, building competences and ultimately leading to superior performance. According to Hernant (2009) performance is a consequence of environmental factors and the extent to which the firm is patronized by consumers, which in turn is a consequence of how well firm attributes like; location, open hours, merchandise, firm layout, service, advertising, correspond to consumers' evaluative criteria for their firm choice behavior. Further, the firm's decision on firm attributes, is influenced by underlying factors, such as local competition and local demand characteristics which enhance or diminish the overall performance of the firm

Performance is the end result of activities and includes the actual outcomes of the organization operational process (Wheelen \& Hunger, 2010). Organizational performance encompasses many specific areas of firm outcomes (Nwokah, 2008). Musah (2008) indicates that organizational performance should be measured through various indicators depending on the organizational structure. In agreement, Kent \& Weese (2000) indicated that performance of the organizations is measured by the congruence between the goals of the organization and the observed outcome. Other authors (Richard et al., 2009; Thang \& Truong, 2011; Morgan et al., 2003) argued that organization performance is related to customer satisfaction, employee satisfaction, increase of the productivity, and superior profit for the organization while Rezaei et al. (2018) suggest the use of multiple indicators in the measurement of organizational performance, which includes both financial and non-financial measures. At the same time with the emergence of the resource-based view (RBV) of the firm, the focus of performance shifted from industry to firm specific assets (Spanos \& Lioukas, 2001). Saleem \& Khurshid (2014) identified employee motivation in the organization as a measure of organizational performance.

In their study Savaneviciene \& Stankeviciute (2010) indicated that whereas profit-oriented organizations tend to measure performance through financial turnover and profitability, non-profit oriented organizations cannot use such measure and thus focus on social benefits to measure performance. In an attempt to determine performance of the firm, empirical literature points that several indicators have been identified as measures of performance to include productivity, quality, innovation, profitability, creativity, commitment, loyalty, decision making, participation, effectiveness, efficiency and effort. In addition to these indicators, Rodwell \& Teo (2004) pointed out that alongside customer loyalty and customer base are also a measure of firm performance.

Organizational performance has been measured using a three-item scale: return on assets, sales growth and increase in market share. Available literature shows the use of these indicators to measure changes in knowledge, competencies and learning of organizations. Shrader (2001) and Stuart (2000), among others, have adopted sales growth; Goerzen \& Beamish (2005), return on assets and Dussauge, Garrette, \& Mitchell (2000), increase in market share. Firm per- 
formance is measured in terms of sales level, profitability, productivity and customer base level.

The efficient market hypothesis assumes that markets are rational (Yalcin et al., 2016). However, a stream of researchers exhibits many observed anomalies that are not explained by the arguments of the efficient market hypothesis. According to Yalcin et al. (2016), heuristics are the shortcuts and rule of thumb caused by data processing errors. They are quite functional to alleviate the cognitive efforts for making the decision process easier which may otherwise require too much time and mental resources. On the other hand, heuristics sometimes cause inevitable biases.

In making credit decisions, financial institutions' credit personnel are guided by objective (collateral) and subjective (know your customer) considerations. Human beings are referred to as making decisions on the basis of their experience and intuition, instead of gathering information, which would encourage them to make better decisions (Shah et al., 2018). Baker \& Nofsinger (2010) observe that investment decision making process is affected by psychological biases, fundamental heuristics and cognitive errors. The study will investigate the effect of these biases on the relationship between credit risk and performance of financial institutions in South Sudan.

\section{Literature}

New banking risk management techniques emerged in early 1990's. To be able to manage the different types of risk one has to define them before one can manage the. Credit risk, interest rate risk, liquidity risk, market risk, foreign exchange risk and solvency risk are the most applicable risk to the banks. Risk management is the human activity which integrates recognition of risk, risk assessment, developing strategies to manage it, and mitigation of risk using managerial resources, but credit risk is the risk of loss due to debtor's non-payment of a loan or other line of credit (either the principal or interest or both) (Campbell, 2007). A commercial bank is an institution that provides financial services, including issuing money in various forms, receiving deposits of money, lending money and processing transactions and the creating of credit. The important of credit risk management to banks cannot be overemphasis and it also form an integral part of the loan process. Credit risk management maximizes bank risk, adjusted risk rate of return by maintaining credit risk exposure with view to shielding the bank from the adverse effects of credit risk.

Credit creation is the main income generating activity for the banks; however, this activity involves huge risks to both the lender and the borrower. A credit risk is the risk of default on a debt that may arise from a borrower failing to make required payments. In the first resort, the risk is that of the lender and includes lost principal and interest, disruption to cash flows, and increased collection costs. Credit risk according to Basel Committee of Banking Supervision (2001) is the possibility of losing the outstanding loan partially or totally, due to 
credit events (default risk). Chin (2010) explains Credit risk as the possibility of loss due to a debtor's non-payment of a loan or other line of credit. The default events include a delay in repayments, restructuring of borrower repayments, and bankruptcy. Credit risk can be defined as the probability that some of the bank's assets will decline in value and perhaps become worthless (Rose \& Hudgins, 2005). Joan, Anthony, \& Anthony (2009) view credit risk as the probability that some of a bans assets, especially its loans, will decline in value and possibly become worthless. Since banks hold little owners' capital relative to the aggregate value of their assets, only a small percentage of total loans need to go bad to push a bank to the brink of failure.

Credit risk is critical since the default of a small number of important customers can cause large losses, which can lead to insolvency (Bessis, 2002). Adesugba \& Bambale (2016) noted that credit risk management is of critical importance for good performance to banks. The largest and most obvious and critical source of credit risk for most commercial banks are loans and advances. However, other sources of credit risk exist throughout the activities of a bank, including in the banking book and in the trading book, and both on and off the balance sheet; limited institutional capacity, inappropriate credit policies, volatile interest rates, poor management, inappropriate laws, low capital and liquidity levels, direct lending, massive licensing of Banks, poor loan underwriting, laxity in credit assessment, poor lending practices, government interference and inadequate supervision by the central Bank (Kithinji, 2010).

It is worth noting that credit risk is also linked with other risks likely to affect the activities of the banks (for example, fluctuating interest rates and other possibly related variables). Credit risk, however, can be a function of other factors such as insufficient knowledge on financial risks and especially credit risk at institution level; lack of appropriate and effectively implantable credit policies, inadequate capital level and unstable liquidity status, laxity in credit assessment, and poor lending practices and procedures. Furthermore, Kithiniji (2010), points out that persisting credit risk gradually impacts liquidity and solvency of banks and may consequently lead to a total a failure.

In their academic works, Jiménez et al. (2006); Samad (2012); Ahmad \& Ariff (2007) pointed out a number of determinants of credit risk in banks; first, inefficient banks performing poor screening and monitoring of borrowers will tend to have inferior portfolio,. Second; Collateralized loans have a high possibility of default because banks tend to trust the borrowers with secured loans and hence less incentives to undertake adequate screening and credit assessment; third; rapid loan growth or credit expansion (over extension of credit) and extended passage of time for profit maximization leads to poor loan quality. Fourth, economic downturn (recession) as external factor affects the ability of individuals, institutions and other borrowers' ability to repay their debts thence high possibility of failure to fulfill their financial commitments.

Thus, credit risk is one of great concern to most bank authorities and banking 
regulators hence credit risk management is critical to banks. Credit risk management is a structured approach to managing uncertainties through risk assessment, developing strategies to manage it and mitigation of risk using managerial resources. The goal of credit risk management is to maximize a bank's risk-adjusted rate of return by maintaining credit risk exposure within acceptable parameters (as per entity's risk appetite) which is a critical component of a comprehensive approach to risk management and essential to the long-term success of any banking organization.

Credit risk management in banks starts with the establishment of sound lending principles and an efficient framework for managing the risk (Oke et al., 2012); the Basel II Accord emphasized on credit risk management practices; compliance with which ensures sound approach to mitigating credit risk consequently achieving improved commercial banks profitability. It also includes measures employed by banks to avoid or minimize the adverse effect of risk such as: the identification, analysis, assessment, control and avoidance, minimization or elimination of unacceptable risks. As a strategy, an organization may use risk assumption, risk avoidance, risk retention, risk transfer or any other strategy (or combination of strategies) in effective management of future events. Therefore, a sound risk management framework is crucial for commercial banks to enhance their profitability and guarantee survival. A sound credit risk management practices are crucial for banks so as to enhance profitability guarantee survival of banks (Oke et al., 2012).

\section{Methodology}

We adopt the the ARDL model in studying the relationship between heuristics and performance of financial institutions in South Sudan. This model is an interventional method for time series models that do not clearly feature the elements of simple and standard OLS as well as Error Correction models (ECM). The method also works with series that are of varying integral order $I(0)$ or $I$ (1), but not $I(2)$ and it carries more preferential weight among econometric researchers because different variables assume different lags as they are fitted into the model Pesaran and Shin, and Pesaran et al. The traditonal ARDL model can be expressed in the following form:

$$
\begin{aligned}
\Delta Y_{t}= & \alpha_{0}+\sum \Phi_{i} \Delta y_{t-i}+\sum \beta_{j} \Delta x_{t-j}+\sum \delta_{k} \Delta z_{t-i}+\theta_{1} y_{t-1} \\
& +\theta_{2} x_{t-1}+\theta_{3} z_{t-1}+u_{t}
\end{aligned}
$$

where $\Phi_{i}, \beta$ and $\delta_{i}$ are the short-run coefficients while $\theta_{1}, \theta_{2}$, and $\theta_{3}$ represent the ARDL long-run coefficients and the error-correction term, $z_{t-1}$ is replaced by the $y_{t-1}, x_{t-1}$, and $z_{t-1}$ terms. Lagged residuals series therefore become $z_{t-1}=\left(y_{t-1}-a_{0}-a_{1} x_{1 t-1} a_{2} x_{2 t-1}\right)$.

\subsection{Model Diagnostics: Serial Correlation}

After estimating our appropriate model equation using the appropriate lag, we carry out model diagnostics by checking for autocorrelation using the 
Breusch-Godfrey Serial Correlation LM Test method under the null hypothesis that there is autocorrelation against of the alternative that errors are either $\operatorname{AR}(m)$ or $\operatorname{MA}(m)$, form $=1,2,3, \ldots$, etc. This is a key element in the assumptions of the ARDL/Bounds Testing methodology of Pesaran et al. (2001). As presented, the $P$-value associated with the Chi-square statistic is way above $10 \%$ hence we cannot reject the null hypothesis that errors are serially independent (Table 1).

\subsection{Model Diagnostics: Dynamic Stability}

We employ the Recursive OLS Estimates-CUSUM Test to determine model stability. The CUSUM (cumulative sum) statistics are defined according to:

$$
\text { CUSUM }_{t}=\sum_{i=k}^{t} w_{i+1, i}
$$

for $t=k, k+1, \cdots, T-1$, where $k=2 p+s+1$ is the minimum sample size for which we can fit the model. Under the null hypothesis, the CUSUM $_{t}$ statistic is drawn from a CUSUM $(t-k)$ distribution. The $\operatorname{CUSUM}_{(t-k)}$ distribution is a symmetric distribution centered at 0 . Its dispersion increases as $t-k$ increases. We reject the null hypothesis at the $5 \%$ significance level if $\operatorname{CUSUM}_{(t-k)}$ is below the 2.5-percentile or above the 97.5-percentile of the $\operatorname{CUSUM}_{(t-k)}$ distribution (Figure 1).

In our study, model stability was carried using Recursive OLS Estimates-CUSUM Test and our results indicates that the trend line lies within the boundaries as shown above. The trend line indicates that the model is stable (Table 2).

From the results, we observe that compliance with the basel accord seem has positive and significant impact on the performance of financial institutions in South Sudan. Evidently, the basel accord has a positive coefficient of 0.1835 with a significance level close to $95 \%$. Similarly, other variables such as monitoring

Table 1. Test of serial correlation.

\begin{tabular}{cccc}
\hline \multicolumn{4}{c}{ Breusch-Godfrey Serial Correlation LM Test } \\
\hline F-statistic & 0.076038 & Prob. F(2, 65) & $P$. value \\
Obs ${ }^{*}$ R-squared & 0.172728 & Prob. Chi-Square(2) & 0.0029 \\
\hline
\end{tabular}

Table 2. ARDL estimation.

\begin{tabular}{ccccc}
\hline Variable & Coefficient & Std. Error & t-Statistic & Prob.* $^{*}$ \\
\hline COMP_BASEL & 0.183497 & 0.106128 & 1.729022 & 0.0884 \\
CROM_PRACTICES & -0.003278 & 0.080428 & -0.040763 & 0.9676 \\
MON_CREDITRISK & 0.092073 & 0.102270 & 0.900293 & 0.3712 \\
RISKMA_ENV & 0.152768 & 0.095811 & 1.594473 & 0.1155 \\
C & 0.738111 & 0.195562 & 3.774301 & 0.0003 \\
\hline
\end{tabular}

Source: Author's calculations. 


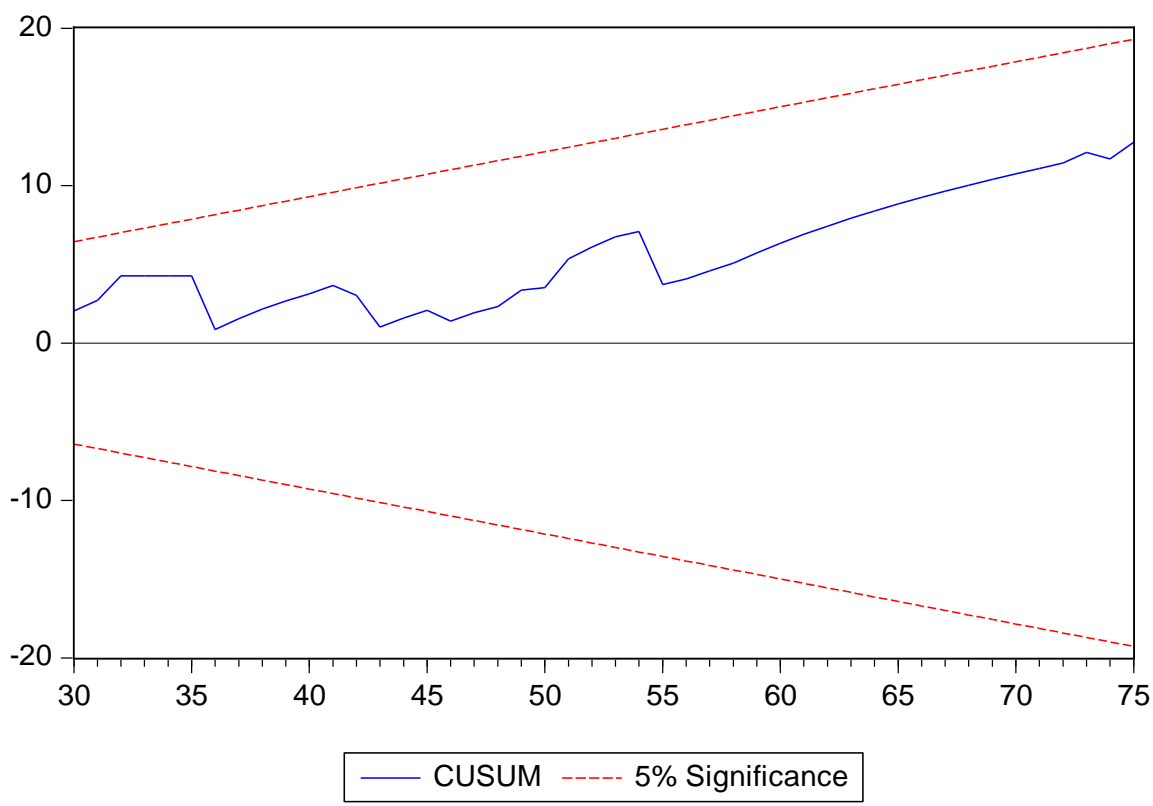

Figure 1. CUSUM test of model stability.

corporate credit risk and risk management environment do have positive effect on the performance of institutions, but rather insignificantly. However, it can be observe that credit risk operational practices negatively affect institutional performances although the effect is insignificant. This implies that credit risk operational practices have the potential to slow or adversely affect the efficiency of financial institutions especially in regards to loan structures.

\section{Conclusion}

This study was conducted to analyze the relationship between credit risk management and the performance of financial institutions in South Sudan. Measures of institutional performance such as compliance with the basel accord, monitoring corporate credit risk, risk management environment and credit risk operational practices were applied. An ARDL model was used to examine the relationship. Our results show that only compliance with the basel accord significantly affects the performance of finance institutions while monitoring corporate credit risk and risk management environment seem not to significantly exact influence the performance of financial institutions in South Sudan. On the other hand, credit risk operational practices seem to negatively and insignificantly affect the performance of financial institutions in the country. Further research in this area may delve into other key sectors such as agriculture and real estate development which are currently having the highest potential in South Sudan.

\section{Conflicts of Interest}

The authors declare no conflicts of interest regarding the publication of this paper. 


\section{References}

Adesugba, A. K., \& Bambale, A. J. (2016). The Effects of Credit Risk Management on the Performance of Some Selected Deposit Money Banks in Nigeria. International Journal of Management and Commerce Innovations, 4, 73-83.

Ahmad, N. H., \& Ariff, M. (2007). Multi-Country Study of Bank Credit Risk Determinants. International Journal of Banking and Finance, 5, 135-152. https://doi.org/10.32890/ijbf2008.5.1.8362

Armstrong, M. (2006). A Handbook of Human Resource Management Practice (10th ed.). Cambridge: Cambridge University Press.

Baker, H. K., \& Nofsinger, J. R. (2010). Behavioral Finance: An Overview. In Behavioral Finance: Investors, Corporations, and Markets (pp. 1-21). Hoboken, NJ: John Wiley \& Sons, Inc. https://doi.org/10.1002/9781118258415.ch1

Bessis, J. (2002). Risk Management in Banking. London: John Wiley \& Sons.

Campbell, J. L. (2007). Why Would Corporations Behave in Socially Responsible Ways? An Institutional Theory of Corporate Social Responsibility. Academy of Management Review, 32, 946-967. https://doi.org/10.5465/amr.2007.25275684

Chin, K. (2010). How to Segment SME Customer Based on Their Risk Profile. http://www.linkedin.com/answers/finance.../risk.../FIN.../674247-32862234

Daft, R. L. (2000). Organization Theory and Design (7th ed.). Boston, MA: South-Western College Publishing Thomson Learning.

Dussauge, P., Garrette, B., \& Mitchell, W. (2000). Learning from Competing Partners: Outcomes and Durations of Scale and Link Alliances in Europe, North America and Asia. Strategic Management Journal, 21, 99-126. https://doi.org/10.1002/(SICI)1097-0266(200002)21:2<99::AID-SMJ80>3.0.CO;2-G

Jiméneza, G., Salas, V., \& Saurina, J. (2006). Determinants of Collateral. Journal of Financial Economics, 81, 255-281. https://doi.org/10.1016/j.jfineco.2005.06.003

Goerzen, A., \& Beamish, P. W. (2005). The Effect of Alliance Network Diversity on Multinational Enterprise Performance. Strategic Management Journal, 26, 333-354.

https://doi.org/10.1002/smj.447

Hernant, M. (2009). Profitability Performance of Supermarkets. The Effects of Scale of Operation, Local Market Conditions, and Conduct on the Economic Performance of Supermarkets. Ph.D. Dissertation, Stockholm: Stockholm School of Economics.

Joan, S., Anthony, Q., \& Anthony, K. (2009). Corporate Governance and Bank Risk Management in Ghana.

http://www.csae.ox.ac.uk/conferences/2011-EDiA/papers/651-Aboagye.pdf

Kent, A., \& Weese, W. J. (2000). Do Effective Organizations Have Better Executive Leadership and/or Organizational Cultures? A Study of Selected Sport Organizations in Canada. European Journal for Sport Management, 7, 4-21.

Kithinji, A. M. (2010). Credit Risk Management and Profitability of Commercial Banks in Kenya. Nairobi: School of Business, University of Nairobi.

Morgan, N. A., Vorhies, D. W., \& Mason, C. (2003). Market Orientation, Marketing Capabilities, and Firm Performance. Strategic Management Journal, 30, 909-920. https://doi.org/10.1002/smj.764

Musah, S. (2008). Evaluating the Extent to Which People and Performance AMO Model Has Contributed to the Strategic Human Resource Debate. Journal of Management, 15, 67-79.

Nwokah, N. G. (2008). Strategic Market Orientation and Business Performance the Study 
of Food and Beverages Organizations in Nigeria. European Journal of Marketing, 42, 279-289. https://doi.org/10.1108/03090560810852922

Oke, M. O., Ayeni, R. K., \& Kolapo, T. F. (2012). Credit Risk and Commercial Bank's Performance in Nigeria: A Panel Model Approach. Australian Journal of Business and Management Research, 2, 31-38.

Pesaran, M. H., Shin, Y., \& Smith, R. J. (2001). Bounds Testing Approaches to the Analysis of Level Relationships. Journal of Applied Econometrics, 16, 289-326.

https://doi.org/10.1002/jae.616

Rezaei, G., Mardani, A., Senin A. A., Wong, K. Y., Sadeghi, L., Najmi, M., \& Shaharoun, A. M. (2018). Relationship between Culture of Excellence and Organisational Performance in Iranian Manufacturing Companies. Total Quality Management \& Business Excellence, 29, 94-115. https://doi.org/10.1080/14783363.2016.1168692

Ricardo, R., \& Wade, D. (2001). Corporate Performance Management: How to Build a Better Organization through Measurement Driven Strategies Alignment. Oxford: Butterworth, Heinemann.

Richard, P. J., Devinney, T. M., Yip, G. S., \& Johnson, G. (2009). Measuring Organizational Performance: Towards Methodological Best Practice. Journal of Management, 35, 718-804. https://doi.org/10.1177/0149206308330560

Rodwell, J., \& Teo, S. T. T. (2004). Strategic HRM in For-Profit and Non-Profit Organizations in a Knowledge-Intensive Industry. Public Management Review, 6, 311-331. https://doi.org/10.1080/1471903042000256510

Rose, C. S., \& Hudgins, S. C. (2005). Bank Management and Financial Services.

Saleem, I., \& Khurshid, A. (2014). Do Human Resource Practices Affect Employee Performance? Pakistan Business Review, 15, 669-688.

Samad, A. (2012). Credit Risk Determinants of Bank Failure: Evidence from US Bank Failure. International Business Research, 5, 10-15. https://doi.org/10.5539/ibr.v5n9p10

Savaneviciene, A., \& Stankeviciute, Z. (2010). The Models Exploring the "Black Box" between HRM and Organizational Performance. Inzinerine Ekonomika Engineering Economics, 21, 426-434.

Shah, S. Z. A., Ahmad, M., \& Mahmood, F. (2018). Heuristic Biases in Investment Decision-Making and Perceived Market Efficiency: A Survey at the Pakistan Stock Exchange. Qualitative Research in Financial Markets, 10, 85-110.

https://doi.org/10.1108/QRFM-04-2017-0033

Shrader, C. (2001). Collaboration and Performance in Foreign Markets, the Case of Young High Technology Manufacturing Firms. Academy of Management Journal, 44, 45-60. https://doi.org/10.2307/3069336

Spanos, Y., \& Lioukas, S. (2001). An Examination into the Causal Logic of Rent Generation: Contrasting Porter's Competitive Strategy Framework and the Resource-Based Perspective. Strategic Management Journal, 22, 907-934.

https://doi.org/10.1002/smj.174

Stuart, T. E. (2000). Interorganizational Alliances and the Performance of Firms, a Study of Growth and Innovation Rates in a High-Technology Industry. Strategic Management Journal, 21, 791-811. https://doi.org/10.1002/1097-0266(200008)21:8<791::AID-SMJ121>3.0.CO;2-K

Thang, N., \& Truong, Q. (2011). The Impact of Training on Firm Performance in a Transitional Economy: Evidence from Vietnam. Research and Practice in Human Resource Management, 19, 11-24.

Wheelen, T. L., \& Hunger, J. D. (2010). Concepts in Strategic Management \& Business 
Policy. London: Prentice Hall.

Yalcin, K. C., Tatoglu, E., \& Zai, S. (2016). Developing an Instrument for Measuring the Effects of Heuristics on Investment Decisions. Kybernetes, 45, 1052-1071.

https://doi.org/10.1108/K-05-2015-0130 